\title{
THE ROLE OF MICROBIAL BIOFILM IN REMOVING AMMONIA IN FLOATING TREATMENT WETLANDS
}

\author{
MUWAFAQ HUSSEIN AL LAMI ${ }^{1,2,3}$, MICHAEL JOHN WHELAN $^{4}$, ARNOUD BOOM $^{4}$, DAVID MALCOLM HARPER ${ }^{2,4,5}$ \\ ${ }^{1}$ Environment Research Centre, University of Technology, Baghdad, Iraq; e-mail: muwafaq.h.mohammed@uotechnology.edu.iq \\ ${ }^{2}$ Department of Biology, College of Life Sciences, University of Leicester, Leicester, United Kingdom \\ ${ }^{3}$ The Higher Committee of Education Development in Iraq, Baghdad, Iraq; e-mail: muwafaqallami@gmail.com \\ ${ }^{4}$ Centre for Landscape and Climate Research, School of Geography, Geology and the Environment, University of Leicester, Leicester, United Kingdom; e-mail: \\ mjw72@leicester.ac.uk, ab269@leicester.ac.uk \\ ${ }^{5}$ Freshwater Biological Association, Far Sawrey, Cumbria LA22 0LP, United Kingdom; e-mail: dmh@leicester.ac.uk
}

$\bowtie$ Corresponding author

Received: 2 June 2020 / Accepted: 18 November 2020

Abstract

Al Lami M.H., Whelan M.J., Boom A., Harper D.M.: The role of microbial biofilm in removing ammonia in floating treatment wetlands. Ekológia (Bratislava), Vol. 40, No. 2, p. 101-114, 2021.

\begin{abstract}
Laboratory experiments were conducted under controlled conditions to quantify the potential of microbial transformation associated with floating matrix of floating treatment wetland (FTW) in ammonia removal and nitrification kinetics. The effect of different design parameters on ammonia removal from synthetic medium was investigated to optimize system performance. Effects of surface area of mat material, range of ammonia concentrations, and aeration on ammonia removal kinetics were studied using microcosm systems. A simple dynamics model of mineral nitrogen transformation was used as a framework for interpreting the experimental results. The results revealed that ammonia removal was enhanced in FTWs, and the magnitude of removal was controlled by the design factors examined. Removal by nitrification was directly proportional to mat surface area. The higher ammonia removal efficiency was caused by a larger surface area, which could support the growth of more microbes. Removal rate constants for treatments were $0.011,0.015,0.026,0.035$, and 0.033 day- 1 for T1, T2, T3, T4, and T5, respectively. There was also a clear inhibitory effect of NH3 on second-stage nitrification manifested as low production of NO3-. Quantitative index of optimized knit/calibrated knit indicated high inhibition effects of NH3 at high concentration of total ammonia ( $60 \mathrm{mg} \mathrm{N} \mathrm{L}-1)$. There was no major effect of oxygen saturation on NHx removal using aerated and nonaerated conditions. Better mechanistic understanding of the fundamental processes operating in FTWs should provide the basis for improving FTW design and efficacy.
\end{abstract}

Key words: nitrification, biofilm, kinetics, inhibition, FTW, dynamics modeling.

\section{Introduction}

Ammonia is one of the most common contaminants discharged into aquatic environments. Removal of ammonia from pollution sources is potential. A number of approaches to remove ammonia have been adopted with varying degrees of success (Cervantes, 2009; Karri et al., 2018). Biological ammonia removal can be accomplished in two types of systems, including suspended and attached growth.

In the environment, most microbes, including nitrifiers, are often found in close-knit communities encased in an extracellular matrix and attached to a surface, forming what are known as microbial biofilms (Park et al., 2015). Therefore, the microbial biomass tends to grow as fixed biofilm more than suspended flocs (Headley, Tanner, 2006). In an attached growth system, this process is also called a fixed film process in which the individual bacteria are immobilized (Chen et al., 2006). In this way, it is possible to obtain a greater microbial biomass in the system to undertake contaminant removal efficiently. Moreover, fixed biofilm can contain a higher concentration of active biomass in which the substrate gradients of the biofilm can be resulted from the development of variant microbial populations (Safwat, 2018). Therefore, as the film builds up, diverse habitats are provided for different transformation processes of contaminants (Shahot et al., 2014). Biofilm kinetics can be complex. The substrate supply into the layer-like aggregation of bacterial film is a diffusion-controlled process driven by the concentration gradient across the biofilm (Chen et al., 2006). The increase of biofilm surface area enables the contaminant to pass over the media and increase the volume of substrate that can be adsorbed from the influent (Maksimova, 2014). This increases the removal efficiency of contaminants.

Floating matrix is fundamental in floating treatment wetland (FTW), as most biochemical processes take place within the mosaic structure of the aerobic and anaerobic zones (Tanner, Headley, 2011). The floating matrix is usually constructed of recycled 
materials and often has a high surface area, which encourages accelerated growth of bacteria (including nitrifiers) (Borne et al., 2013; Allami et al., 2021). A number of studies have investigated FTW performance in removing nitrogen, including ammonia, using different removal pathways (Faulwetter et al., 2011; Ijaz et al., 2015; Vázquez-Burney et al., 2015). However, most of these studies have adopted black-box approaches to quantify overall removal rates without specifically investigating the relative contribution of different removal processes. Information is often unavailable about the effect of biofilm surface area associated with floating matrix on ammonia removal and nitrification kinetics. There is limited if any information on the role of surface area as a design parameter to optimize system performance in removing ammonia.

The aim of this study was to quantify the key factors on ammonia removal in FTW systems, including different surface areas of floating mat, range of ammonia concentrations, and aeration: (a) the effect of different biofilm surface areas, (b) the effect of ammonia concentration, and (c) the effect of aeration. A simple model of mineral nitrogen transformation was used as a framework for interpreting the experimental results. We hypothesize that nitrification rate is directly and linearly proportional to the mat surface area (i.e., that nitrifiers predominantly inhabit fixed biofilms attached to the mat). We also hypothesize that nitrification rate will be inhibited at higher free ammonia concentrations and that nitrification will be enhanced by aeration (i.e., that oxygen will limit nitrification in unaerated systems). Better mechanistic understanding of the fundamental processes operating in FTWs should provide the basis for improving FTW design and efficacy.

\section{Material and methods}

\section{Experimental}

Prior to the experimental phase, floating mat material consisting of extruded plastic (obtained from Frog Environmental, UK) was precut into pieces approximately $2 \mathrm{~cm}^{2}$ and weighing 0.570 $\pm 0.054 \mathrm{~g}$. The cut mat materials were incubated for 4 weeks in $5000-\mathrm{mL}$ conical glass flasks containing $4000 \mathrm{~mL}$ of mineral medium, and approximately $200 \mathrm{~g}$ of sediment collected from a local pond. Substrate media contained $0.272 \mathrm{mM} \mathrm{MgSO}_{4}, 0.6 \mathrm{mM}$ $\mathrm{CaCl}_{2}, 0.24 \mu \mathrm{M} \mathrm{FeSO}_{4}, 0.174 \mu \mathrm{M}$ EDTA, $3 \mathrm{mM} \mathrm{K}_{2} \mathrm{HPO}_{4}$, and 1.4 $\mu \mathrm{M}$ phenol red and prepared in deionized water (Chapman et al., 2006). The sediment was used as a mixed culture of microorganisms to allow biofilms to develop. The flasks were covered with foil to maintain dark conditions for microbial growth and to prevent algal growth. Stock cultures were fed on a daily basis by adding $4 \mathrm{~mL}$ of $1 \mathrm{M} \mathrm{NH}_{4} \mathrm{HCO}_{3}$ to encourage nitrifier growth and biofilm establishment (Al Obaidy et al., 2017). Cultures $\mathrm{pH}$ were readjusted daily to $\mathrm{pH} 7.4$, depending on the phenol red color change, using $0.1 \mathrm{M} \mathrm{Na}_{2} \mathrm{CO}_{3}$. All flasks were capped with a rubber bung fitted with a tube for aeration via an air stone attached to an aquarium pump. Gas venting of the headspace was achieved via a water trap (brewers' trap) containing a disinfectant. The temperature was maintained at $29^{\circ} \mathrm{C}$ using thermostats. $\mathrm{pH}$, temperature, and dissolved oxygen (DO) were monitored daily using a Hanna HI 8711E pH meter (Hanna Instruments Inc.) and YSI Professional Plus multi-probe meter (Yellow Springs International Inc. Ohio, USA).
Two microcosm experiments were established. Experiments 1 investigated the effect of mat area on ammonia removal. For this, $1000-\mathrm{mL}$ amber Duran glass bottles were used at room temperature $\left(20-21^{\circ} \mathrm{C}\right)$. The same volume of synthetic mineral media spiked with ammoniacal nitrogen was used in all treatments. $\mathrm{pH}$ was maintained (between 7.3 and 7.4) by adding 0.1 $\mathrm{M} \mathrm{Na}_{2} \mathrm{CO}_{3}$. All treatments were established in triplicate. The treatments were as follows: $\mathrm{T}_{1}\left(4 \mathrm{~cm}^{2}\right.$ mat material $), \mathrm{T}_{2}\left(8 \mathrm{~cm}^{2}\right.$ mat material $), T_{3}\left(12 \mathrm{~cm}^{2}\right.$ mat material $), T_{4}\left(16 \mathrm{~cm}^{2}\right.$ mat material), $\mathrm{T}_{5}\left(20 \mathrm{~cm}^{2}\right.$ mat material), and control (no mat material). The initial concentration of ammonia- $\mathrm{N}$ in each treatment was $72 \pm 2 \mathrm{mg} \mathrm{N} \mathrm{L}^{-1}$. The bottles were gently shaken daily.

Experiment 2 investigated the influence of different concentrations of ammonia under aerated and nonaerated conditions on nitrification kinetics. The treatments were as follows: $\mathrm{T}_{1}(15$ mg N L ${ }^{-1}$ without aeration), $\mathrm{T}_{2}$ (15 $\mathrm{mg} \mathrm{N} \mathrm{L}^{-1}$ with aeration), $\mathrm{T}_{3}$ (30 $\mathrm{mg} \mathrm{N} \mathrm{L}^{-1}$ without aeration), $\mathrm{T}_{4}\left(30 \mathrm{mg} \mathrm{N} \mathrm{L}^{-1}\right.$ with aeration), $\mathrm{T}_{5}\left(60 \mathrm{mg} \mathrm{N} \mathrm{L}^{-1}\right.$ without aeration), and $\mathrm{T}_{6}\left(60 \mathrm{mg} \mathrm{N} \mathrm{L}^{-1}\right.$ with aeration). All treatments used a mat area of $20 \mathrm{~cm}^{2}$. All treatments were aerated using aquarium air pumps $\left(50 \mathrm{~L} \mathrm{hr}^{-1}\right)$. Airflow rate in each reactor was monitored using a bubble flow meter.

In each experiment, aqueous samples $(15 \mathrm{~mL})$ were collected from each bottle for nine sampling intervals over a 2-week period. Samples for total ammoniacal $\mathrm{N}\left(\mathrm{NH}_{\mathrm{x}}\right)$ and total oxidized $\mathrm{N}\left(\mathrm{NO}_{\mathrm{x}}\right)$ analysis were immediately preserved by adding 0.025 $\mathrm{mL}$ of concentrated sulfuric acid (98\%) and cooling to $4^{\circ} \mathrm{C}$ (EPA, 1993). Samples for nitrite analysis were either analyzed directly or frozen at $-20^{\circ} \mathrm{C}$ until analysis (Cheeseman et al., 1989). Concentrations of $\mathrm{NH}_{x}, \mathrm{NO}_{2}^{-}$, and $\mathrm{NO}_{\mathrm{x}}$ were analyzed according to established protocols (SEAL Analytical, 2011, 2013, 2015) using an automated discrete colorimetric instrument (AQ2: SEAL Analytical, UK). Unionized $\mathrm{NH}_{3}$ concentration was calculated assuming full and instantaneous thermodynamic equilibrium between $\mathrm{NH}_{3}$ and $\mathrm{NH}_{4}^{+}$. DO, $\mathrm{pH}, \mathrm{EC}$, and temperature were measured at the time of each sampling using portable probes (see inoculation phase).

Ammonia removal in the two experiments was assumed to follow first-order kinetics. In first-order kinetics (Finnegan et al., 2009; Lin et al., 2002):

$$
C_{t}=C_{i} e^{-k \cdot t} \text {, }
$$

where $C_{t}$ is the concentration at time $t\left(\mathrm{mg} \mathrm{N} \mathrm{L}^{-1}\right), C_{i}$ is the initial concentration $\left(\mathrm{mg} \mathrm{N} \mathrm{L}^{-1}\right), k$ is the removal rate constant $\left(k_{\text {amo }}, k_{\text {nit. }}\right.$ and $k_{\text {denit }}$ day $\left.{ }^{-1}\right)$, and $t$ is the reaction time (day).

Removal rate constants for ammonia $\left(k_{\text {nit }}\right)$ for different treatments were calculated as follows:

$$
k=\frac{\ln \left(C_{\mathrm{fin}} / C_{\mathrm{init}}\right)}{t},
$$

where $k$ is the removal rate constant for $\mathrm{NH}_{\mathrm{x}}\left(\right.$ day $\left.^{-1}\right), \mathrm{C}_{\text {init }} /$ in the initial or final concentration $\left(\mathrm{mg} \mathrm{N} \mathrm{L}^{-1}\right)$, and $t$ is the reaction time (day). The reaction time for these experiments was simply the time from initiation to sampling.

The half-life (day) of the $\mathrm{N}$-forms dynamic in the system was calculated as follows (Finnegan et al., 2009):

$$
T_{1 / 2} \frac{\ln (2)}{k},
$$


where $T_{1 / 2}$ is the half-life (day) and $k$ is the removal rate constant for $\mathrm{NH}_{x}\left(\right.$ day $\left.^{-1}\right)$.

The losses of ammonia-N via volatilization of unionized ammonia was estimated, assuming full and instantaneous thermodynamic equilibrium between $\mathrm{NH}_{3}$ and $\mathrm{NH}_{4}^{+}$(Whelan et al., 2010):

$$
C_{\mathrm{NH}_{3}}=C_{\mathrm{NH}_{\mathrm{x}}} \cdot f_{\mathrm{FREE}},
$$

where $C_{\mathrm{NHx}}$ is the concentration of total ammonia $\mathrm{N}\left(\mathrm{mg} \mathrm{L}^{-1}\right)$ and $f_{\mathrm{FREE}}$ is the fraction of $\mathrm{NH}_{3}$, which is

$$
f_{\mathrm{FREE}}=\left(\frac{1}{1+10^{(p K a-p H)}}\right) \text {. }
$$

In which, $p K a$ is the temperature-dependent dissociation constant, which was set at 9.24 (for system temperature of $25^{\circ} \mathrm{C}$ ) (Finnegan et al., 2009).

A combined mass transfer coefficient $-k_{T}\left(\mathrm{~m} \mathrm{~h}^{-1}\right)$ can be calculated using the two-film resistance model (Kadlec, Wallace, 2009) as follows:

$$
\frac{1}{k_{T}}=\frac{1}{k_{W}}+\frac{1}{k_{A} \cdot k_{A W}} .
$$

In which $k_{A}$ and $k_{W}$ are partial mass transfer coefficients for the air side $\left(\mathrm{m} \mathrm{h}^{-1}\right)$ and water side of the air-water interface $\left(\mathrm{m} \mathrm{h}^{-1}\right)$, respectively, and $k_{A W}$ is the air: water partition coefficient for $\mathrm{NH}_{3}$ (dimensionless Henry's law constant: 0.0007). Values for $k_{A}$ and $k_{W}$ were set at 1 and $0.01 \mathrm{~m} \mathrm{~h}^{-1}$, respectively (Mackay, 2001).

The volatilization rate coefficient $\left(k_{\text {vol }}\right.$, day $\left.{ }^{-1}\right)$ was estimated by dividing $k_{T}$ by water depth (. The rate constant for the loss of ammonia- $\mathrm{N}$ by volatilization of $\mathrm{NH}_{3}$ is therefore (Whelan et al., 2010)

$$
k_{\mathrm{vol}}=\frac{k_{T}}{\mathrm{Z}} \cdot f_{\frac{\mathrm{NH}_{3}}{\mathrm{NH}_{4}}} \cdot
$$

\section{Model}

A simple numerical model was developed to describe $\mathrm{NH}_{\mathrm{x}}$ and $\mathrm{NO}_{2}{ }^{-}$behavior in each experiment. Experimental data obtained from one treatment $\left(\mathrm{T}_{5}\right)$ in experiment 1 were used for model calibration (Table 1). The model fit to the measured $\mathrm{NH}_{\mathrm{x}}$ concentration data was optimized by minimizing the root mean square error (RMSE) between the simulated and measured concentrations in a trial-and-error optimization of the parameter $k_{\text {nit }}$ (Rousseau et al., 2004). The model was run over 14 days and employed Euler's method of integration with a time step of 0.25 day.

The mass balance equation for the total ammonia $\mathrm{N}$ is expressed as follows:

$$
V . \frac{d\left[N H_{x}\right]}{d t}=k_{\mathrm{vol}} \cdot f_{\mathrm{FREE}} \cdot\left[N H_{x}\right] \cdot V-k_{\mathrm{nit}} \cdot\left[N H_{x}\right] . V,
$$

where $k_{\mathrm{vol}}$ is the mass transfer coefficient of free ammonia across the air-liquid interface by volatilization $\left(\right.$ day $\left.^{-1}\right), f_{\mathrm{FREE}}$ is the fraction of total ammonia that is present as free $\mathrm{NH}_{3}$ (dependent on $\mathrm{pH}$ and temperature), $k_{\text {nit }}$ is a first-order rate constant for nitrification $\left(\right.$ day $\left.^{-1}\right),\left[\mathrm{NH}_{x}\right]$ is the total ammonia-N concentration in the treatment $\left(\mathrm{mg} \mathrm{N} \mathrm{L}^{-1}\right)$, and $V$ is the vessel volume (L).

The calibrated value for $k_{\text {nit }}$ was then adjusted in proportion to the mat area for other treatments after subtracting the background control value for $k$ (kcontrol). This represents the background nitrification rate due to biofilm on the surfaces of the vessel. A specific rate constant $\left(k_{\text {spec }}\right)$ per unit mat area $(A)$ was estimated for $\mathrm{T}_{5}$ by dividing $k_{\text {nit }}$ by the total surface area of the mats. $k_{\text {spec }}$ of $\mathrm{T}_{5}(0.0015)$, mat surface area $(A)$, and $k$ control were used to calculate predicted overall rate constants $\left(k_{\text {indep }}\right)$ for other treatments.

$$
\text { kindep }=\text { kcontrol }+(k \operatorname{spec} T 5 * A),
$$

\begin{tabular}{|c|c|c|c|}
\hline STELLA symbol & Description & Initial value/Units & Source \\
\hline \multicolumn{4}{|l|}{ State variables } \\
\hline $\mathrm{NH}_{\mathrm{xini}}$ & $\mathrm{NH}_{3}+\mathrm{NH}_{4}^{+}$mass & $72.25 \mathrm{mg} \mathrm{N}$ & \\
\hline $\mathrm{NO}_{2}^{-}$ & $\mathrm{NO}_{2}$ mass & $\mathrm{mg} \mathrm{N}$ & \\
\hline Volatized $\mathrm{NH}_{3}$ & Free ammonia volatilization & $\mathrm{mg} \mathrm{N}$ & \\
\hline \multicolumn{4}{|l|}{ Flow variables } \\
\hline$J_{\text {nit }}$ & Nitrification rate & $\mathrm{mg} \mathrm{N}$ day $^{-1}$ & Calculated using data in T5 \\
\hline$J_{v o l}$ & Volatilization rate & $\mathrm{mg} \mathrm{N}$ day $^{-1}$ & (Whelan et al., 2010) \\
\hline \multicolumn{4}{|c|}{ Parameters/coefficients } \\
\hline$\left[\mathrm{NH}_{\mathrm{x}}\right]$ & $\mathrm{NH}_{\mathrm{x}}$ concentration & $\mathrm{mg} \mathrm{N} \mathrm{L}^{-1}$ & \\
\hline$k_{n i t}$ & Nitrification rate constant & 0.033 day $^{-1}$ & Calculated using data in T5 \\
\hline$k_{v o l}$ & Mass transfer coefficient of $\mathrm{NH}_{3}$ & 0.08 day $^{-1}$ & Estimated using data in T5 \\
\hline $\mathrm{NH}_{3 \mathrm{f}}$ & Concentration of $\mathrm{NH}_{3}$ gas & $0.015 \mathrm{mg} \mathrm{N}$ & Estimated using data in T5 \\
\hline $\mathrm{V}$ & volume & $\mathrm{L}$ & \\
\hline
\end{tabular}

Since adjustment to the rate constants for the other treatments was made only using the surface area, these predictions can be considered to be an independent validation.

Table 1. Description of symbols used in the microcosm model. T5 is treatment number 5 (containing $20 \mathrm{~cm} 2$ mat material). 

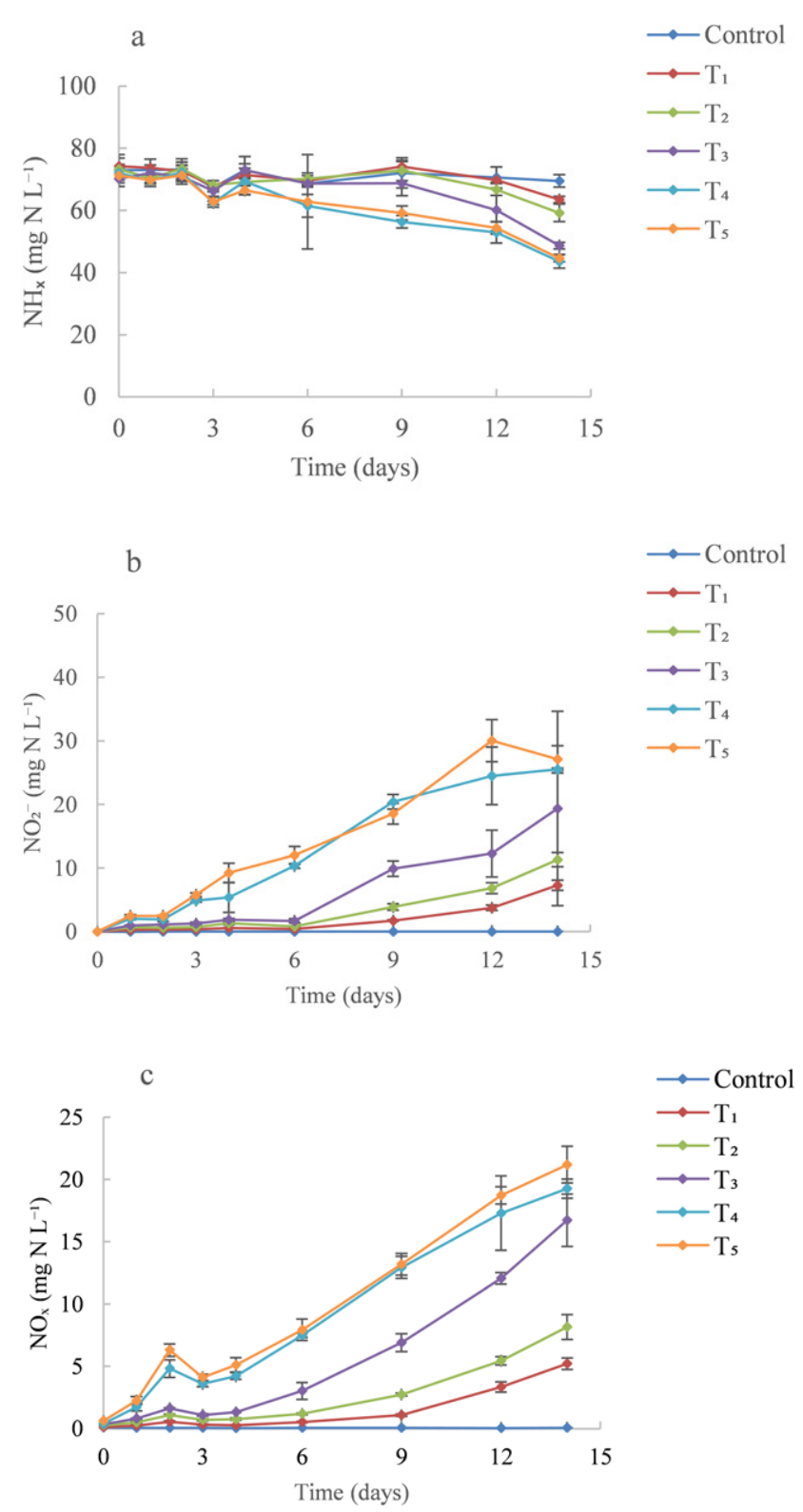

Fig. 1. Changes in the concentration of (a) $\mathrm{NH}_{x}$, (b) $\mathrm{NO}_{2}$, (c) $\mathrm{NO}_{x}$ over time (mean \pm standard deviation). Control (without mat); $\mathrm{T}_{1}(4$ $\mathrm{cm}^{2}$ mat material); $\mathrm{T}_{2}\left(8 \mathrm{~cm}^{2}\right.$ mat material); $\mathrm{T}_{3}\left(12 \mathrm{~cm}^{2}\right.$ mat material); $\mathrm{T}_{4}\left(16 \mathrm{~cm}^{2}\right.$ mat material); $\mathrm{T}_{5}\left(20 \mathrm{~cm}^{2}\right.$ mat material $)$.

Table 2. Net removal (mg N L-1), rate constant $\left(k\right.$, day $\left.{ }^{-1}\right)$, and halflives $\left(T_{1 / 2}\right.$, day) for the $\mathrm{NH}_{\mathrm{x}}$ concentrations in the treatments.

\begin{tabular}{|c|c|c|c|}
\hline & $\begin{array}{c}\text { Net removal } \\
\left(\mathrm{mg} \mathrm{N} \mathrm{L}^{-1}\right)\end{array}$ & $\begin{array}{c}\boldsymbol{k} \\
\left(\text { day }^{-1}\right)\end{array}$ & $\begin{array}{c}\boldsymbol{T}_{1 / 2} \\
(\text { day })\end{array}$ \\
\hline Control & 3.47 & 0.003 & 198.73 \\
\hline $\mathrm{T}_{1}$ & 10.78 & 0.011 & 61.85 \\
\hline $\mathrm{T}_{2}$ & 14.03 & 0.015 & 45.59 \\
\hline $\mathrm{T}_{3}$ & 21.57 & 0.026 & 26.43 \\
\hline $\mathrm{T}_{4}$ & 28.46 & 0.035 & 19.31 \\
\hline $\mathrm{T}_{5}$ & 26.63 & 0.033 & 20.73 \\
\hline
\end{tabular}

The calibrated value of $k_{\text {nit }}$ derived from experiment 1 was also applied to other treatments from experiment 2 to compare ammonia loss in both experiments and to illustrate the extent of the inhibition effect of free $\mathrm{NH}_{3}$ on nitrification. Then, the calibrated $k_{\text {nit }}$ value was optimized for each treatment to get best fits between simulated and measured concentrations. Optimized $k_{\text {nit }}$ were compared with calibrated $k_{\text {nit }}$ from experiment 1 . The ratio of optimized $k_{\text {nit }}$ to calibrated $k_{\text {nit }}$ int was regarded as a quantitative index of the extent of nitrifier inhibition by free $\mathrm{NH}_{3}$.

A statistical comparison between observed and simulated datasets of the concentration of different $\mathrm{N}$ species in each experiment was made to assess the accuracy of the model. Linear regression was used to determine the significance of the relationship between simulated and measured concentrations. The coefficient of determination $\left(\mathrm{R}^{2}\right)$, slope of the linear regression, and RMSE were employed to compare actual and modeled data sets (Abadi et al., 2015).

$$
R M S E=\sqrt{\frac{\sum_{i=1}^{n}\left(O_{i}-S_{i}\right)^{2}}{n}},
$$

where $O_{i}$ and $S_{i}$ are the observed and simulated values of the variable under consideration for a time step and $n$ is the number of observations.

Two-way analysis of variance (ANOVA) and linear regressions were employed (Field et al., 2012). Three replicates were always used for each variable, and the data presented represent averages unless otherwise stated. Error bars represent standard deviations. The Shapiro-Wilk test for homogeneity of variances and normality was performed to test the distribution of the data. In cases of significant differences in ANOVA, Tukey's post hoc test was used to analyze any significance between samples means (Rohatgi, Saleh, 2015). The level of significance was set at $p<$ 0.05 . Correlations between variables were assessed using Pearson correlation analysis. All statistical analysis was performed using Microsoft Excel and R (R-Studio v. 099.489).

\section{Results}

\section{Effect of mat area (experiment 1)}

Changes in the concentration of ammonia, nitrite, and total oxidized $\mathrm{N}$ over time for each treatment are shown in Fig. $1 . \mathrm{NH}_{\mathrm{x}}$ reduction was observed in all treatments soon after the introduction of the mat material, which continued over the 14-day experimental period. $\mathrm{NH}_{\mathrm{x}}$ removal differed significantly between treatments (ANOVA; $F_{5,54}=9.276 ; P<0.05$ ).

Higher ammonium removal was observed as mat surface area increased indicating higher biofilm activity associated with high surface area than with those with low surface area. Consistently, higher rate constants were observed in $\mathrm{T}_{4}$ and $\mathrm{T}_{5}$ treatments compared to $\mathrm{T}_{1}, \mathrm{~T}_{2}$, and $\mathrm{T}_{3}$, respectively. In contrast, removal half-lives for $\mathrm{NH}_{\mathrm{x}}$ concentrations within $\mathrm{T}_{4}$ and $\mathrm{T}_{5}$ treatments were shorter than $\mathrm{T}_{1}, \mathrm{~T}_{2}$, and $\mathrm{T}_{3}$, respectively (Table 2 ).

The observation of an increased rate of nitrification with an increase in the mat area is consistent with the expectation that microbial processes are closely associated with solid surfaces (Kadlec, Wallace, 2009). The rate constants for $\mathrm{NH}_{\mathrm{x}}$ are plotted against mat surface area in Fig. 2. 
Table 3. Average concentrations of $\mathrm{NH}_{3}$ in the treatments during the experiment

\begin{tabular}{|c|c|c|c|c|c|c|}
\hline \multicolumn{7}{|c|}{ Treatments } \\
\hline \begin{tabular}{c}
\hline \multicolumn{2}{|c|}{ Control } & $\mathbf{T}_{1}$ & $\mathbf{T}_{2}$ & $\mathbf{T}_{3}$ & $\mathbf{T}_{4}$ & $\mathbf{T}_{5}$ \\
$\left(\mathrm{mg} \mathrm{N} \mathrm{L}^{-1}\right)$
\end{tabular} & $1.1 \pm 0.06$ & $1.06 \pm 0.08$ & $1.01 \pm 0.09$ & $0.96 \pm 0.11$ & $0.92 \pm 0.16$ & $0.92 \pm 0.11$ \\
\hline
\end{tabular}

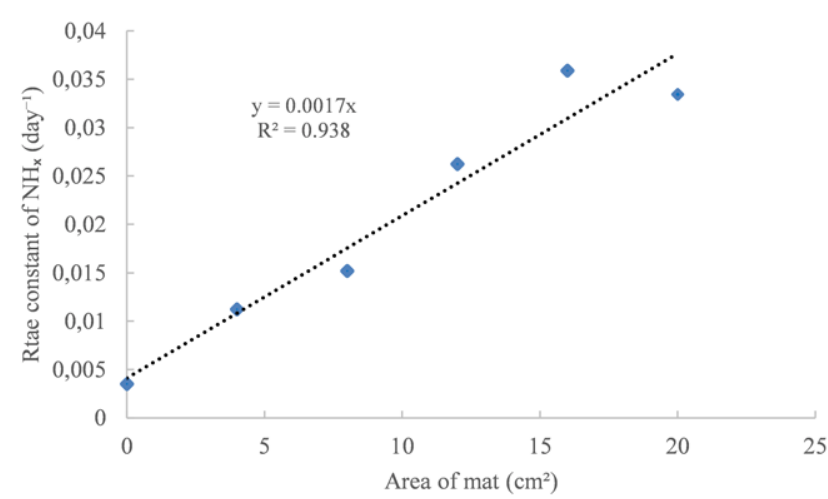

Fig. 2. Removal rate constants of $\mathrm{NH}_{\mathrm{x}}$ at different area of floating mats.

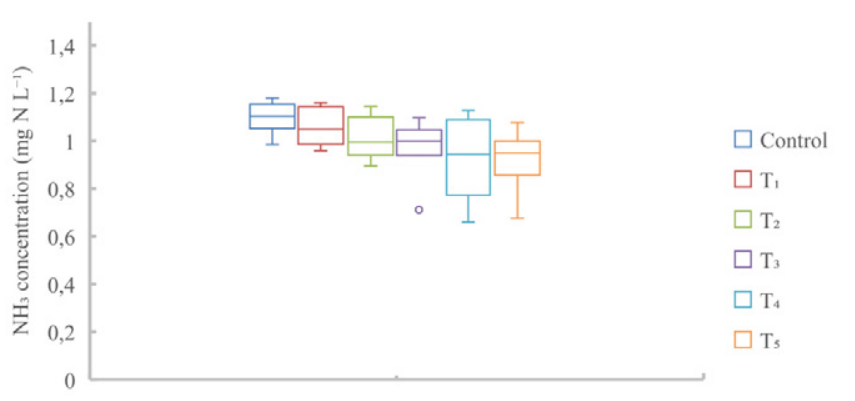

Treatments

Fig. 3. Concentration of $\mathrm{NH} 3$ in treatments under different areas of mat material

Rate constant was positively correlated with the increase of mat area $\left(r^{2}=0.96 ; p=0.05\right)$. These results are in good agreement with those obtained by Wang et al., (2015), who reported higher removal efficiency of $\mathrm{NH}_{x}(89-91 \%)$ when the surface area of floating mat was increased by adding a biological grid that allows for larger bacterial populations.

In parallel, nitrite concentrations increased over time. The rate of $\mathrm{NO}_{2}^{-}$production was initially low and then increased after 3-6 days. The rate of $\mathrm{NO}_{2}{ }^{-}$production was consistent with the rate of $\mathrm{NH}_{\mathrm{x}}$ loss and was highest in $\mathrm{T}_{4}$ and $\mathrm{T}_{5}$, which had the highest mat surface area (Fig. 1b). Initial delay of nitrification activity in the treatments at the start of the experiment (lag phase) could be attributed to acclimatization of the microbial population to the high concentration of ammonia in this system. The most prolonged lag phase was observed in the treatments with smaller mat area $\left(\mathrm{T}_{1}, \mathrm{~T}_{2}\right.$, and $\left.\mathrm{T}_{3}\right)$. A possible explanation is that higher microbial biofilm is metabolically capable of tolerating
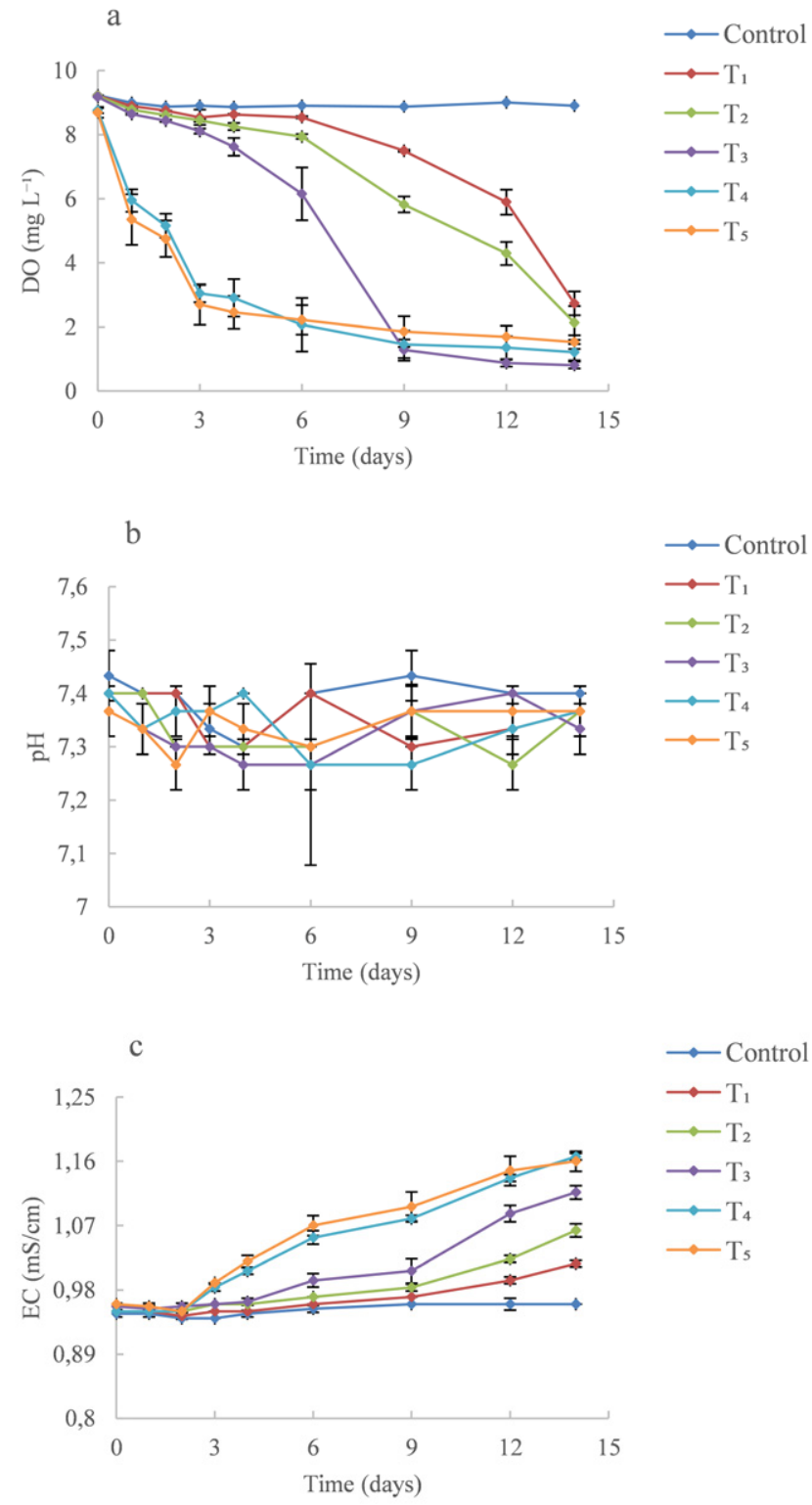

Fig. 4. Changes in the (a) DO; (b) $\mathrm{pH}$ and (c) EC over time (mean \pm standard deviation). Control (without mat); $\mathrm{T}_{1}\left(4 \mathrm{~cm}^{2}\right.$ mat material); $\mathrm{T}_{2}\left(8 \mathrm{~cm}^{2}\right.$ mat material); $\mathrm{T}_{3}\left(12 \mathrm{~cm}^{2}\right.$ mat material $) ; \mathrm{T}_{4}\left(16 \mathrm{~cm}^{2}\right.$ mat material); $\mathrm{T}_{5}\left(20 \mathrm{~cm}^{2}\right.$ mat material $)$.

and nitrifying high concentration of $\mathrm{NH}_{\mathrm{x}}$ faster than those with a smaller amount of biofilm (Costerton et al., 1994). Treatments with higher mat area had higher accumulated concentrations of $\mathrm{NO}_{2}^{-}$(ANOVA, $\left.F_{5,54}=10.088 ; p<0.05\right)$. The net production of $\mathrm{NO}_{2}{ }^{-}$concentration were $7.27,11.3,19.36,25.5$, and $27.1 \mathrm{mg} \mathrm{N}$ 
Table 4. Calibrated $k_{\text {nit }}$ for $\mathrm{T}_{5}$ and calculated $k_{\text {inde }}$ for independent treatments.

\begin{tabular}{|c|c|c|c|c|c|}
\hline $\begin{array}{c}\boldsymbol{k}_{\text {nit }^{1}} \\
\text { day }^{1} \text { ) }\end{array}$ & \multicolumn{5}{|c|}{$\begin{array}{c}k_{\text {inde }} \\
\left.\text { day }^{1}\right)\end{array}$} \\
\hline $\mathbf{T}_{5}$ & Control & $\mathbf{T}_{1}$ & $\mathbf{T}_{2}$ & $\mathbf{T}_{3}$ & $\mathbf{T}_{4}$ \\
\hline 0.0333 & 0.0035 & 0.0095 & 0.0155 & 0.0215 & 0.0274 \\
\hline
\end{tabular}

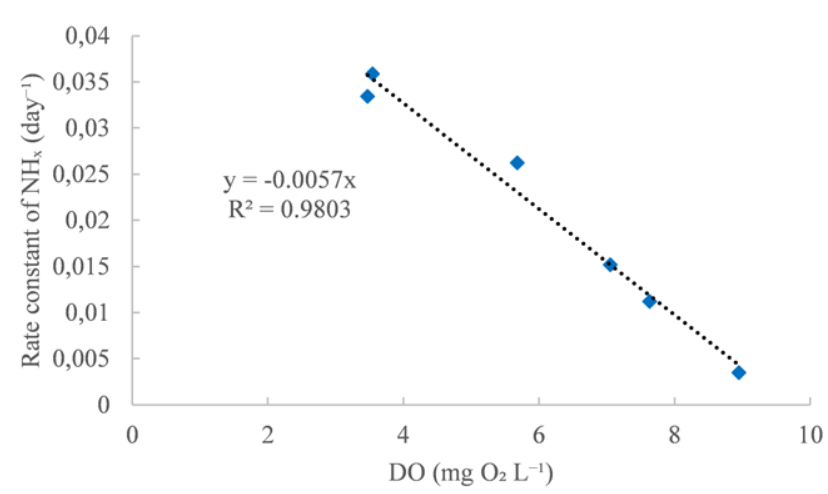

Fig. 5. Removal rate constants of $\mathrm{NH}_{\mathrm{x}}$ versus DO concentrations in the treatments.

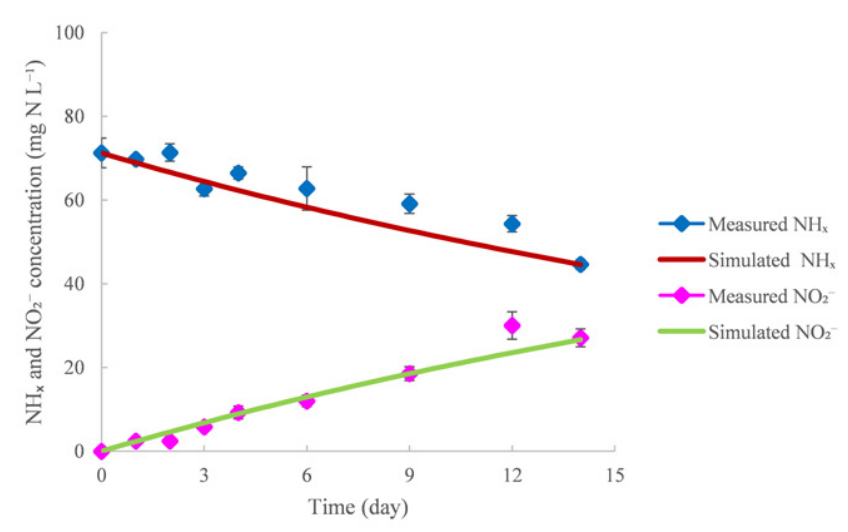

Fig. 6. Measured time series of mean $\mathrm{NH}_{x}$ and $\mathrm{NO}_{2}{ }^{-}$concentrations in the $\mathrm{T}_{5}$ treatment (symbols) and simulated values (lines) produced using the calibrated parameters. Error bars shows standard deviations.
$\mathrm{L}^{-1}$ in $\mathrm{T}_{1}, \mathrm{~T}_{2}, \mathrm{~T}_{3}, \mathrm{~T}_{4}$, and $\mathrm{T}_{5}$, respectively. $\mathrm{NO}_{2}^{-}$concentration in the control treatment remained very low $\left(0.001 \mathrm{mg} \mathrm{N} \mathrm{L}^{-1}\right)$.

Total oxidized $\mathrm{N}$ concentrations in all treatments were similar to those of nitrite suggesting that there was very little production of nitrate (Fig. 1c). This indicates that the growth and activity of Nitrobacter spp. responsible for the conversion of $\mathrm{NO}_{2}^{-}$to $\mathrm{NO}_{3}{ }_{3}^{-}$ was inhibited in this experimental system. The most likely explanation for this is that the concentration of $\mathrm{NH}_{3}$ was high. There is a general agreement that Nitrosomonas are less sensitive to high $\mathrm{NH}_{3}$ concentrations than Nitrobacter (Park et al., 2010). Inhibition of Nitrosomonas is usually reputed in the range of $10-150 \mathrm{mg} \mathrm{N}$ $\mathrm{L}^{-1}$, whereas for Nitrobacter, it can start in the concentration range 0.1-1.0 $\mathrm{mg} \mathrm{N} \mathrm{L}^{-1}$ (Anthonisen et al., 1976). The dynamics of $\mathrm{NH}_{3}$ alongside with average concentrations in the treatments throughout the experiment are presented in Fig. 3 and Table 3. The range of $\mathrm{NH}_{3}$ concentrations observed $\left(0.9-1.1 \mathrm{mg} \mathrm{NH}_{3} \mathrm{~L}^{-1}\right)$ are consistent with those reported earlier, which might explain the inhibition effect of free ammonia on Nitrobacter spp., thereby depressing the conversion of $\mathrm{NO}_{2}^{-}$to $\mathrm{NO}_{3}^{-}$.

DO concentrations differed between treatments (ANOVA, $\left.F_{5,54}=18.864 ; P<0.05\right)$. There was an exponential decrease in DO concentrations in $\mathrm{T}_{4}$ and $\mathrm{T}_{5}$ from time zero to an asymptote at almost 9 days. Decreases in DO concentrations were also seen in the other treatments containing mat material, but the rate of change here was initially slow and increased progressively in $\mathrm{T}_{1}$ and $\mathrm{T}_{2}$ over the course of the experiment (Fig. 4a). In $\mathrm{T}_{3}, \mathrm{DO}$ concentration also reached an asymptote at 9 days. The rate of change in DO concentration appeared to be proportional to the nitrification rate. In control, there was very little DO depression. Nitrifying bacteria are obligate aerobes and require oxygen to derive energy from reduced ammonia (Hargreaves, 1998).

The observation of an increased rate of nitrification with the decreased DO concentration is consistent with the expectation that ammonia oxidation is correlated with $\mathrm{DO}$ and can be regarded as the primary sink of the DO. The rate constants for $\mathrm{NH}_{x}$ are plotted against DO concentration in Fig. 5. A negative correlation was observed between removal rate constant of ammonia and DO concentration $\left(\mathrm{r}^{2}=0.99 ; p=0.05\right)$.

Although there was a clear reduction in the DO concentration in the treatments with mat materials over the course of the experiment, the measured $\mathrm{O}_{2}$ levels in the media were not limiting to the microbial activity (e.g., $>2 \mathrm{mg} \mathrm{O}_{2} \mathrm{~L}^{-1}$ ). Since media $\mathrm{pH}$ during the experiment was maintained between 7.3 and 7.4 (Fig. 4b), volatilization was calculated to be low in all treatments. The loss of ammonia via volatilization of $\mathrm{NH}_{3}$ was found to be $0.001 \mathrm{day}^{-1}$. In

Table 5. Statistical analysis for model performance.

\begin{tabular}{|c|c|c|c|c|c|c|}
\hline & \multicolumn{3}{|c|}{ NH $_{x}$} & \multicolumn{3}{c|}{ NO $_{2}^{-}$} \\
\hline & $\mathrm{R}^{2}$ & $\begin{array}{c}\text { Slope } \\
\left(\mathrm{mg} \mathrm{N} \mathrm{L}^{-1}\right)\end{array}$ & $\begin{array}{c}\text { RMSE } \\
\left(\mathrm{mg} \mathrm{N} \mathrm{L}^{-1}\right)\end{array}$ & $\mathrm{R}^{2}$ & $\begin{array}{c}\text { Slope } \\
\left(\mathrm{mg} \mathrm{N} \mathrm{L}^{-1}\right)\end{array}$ & $\begin{array}{c}\text { RMSE } \\
\left(\mathrm{mg} \mathrm{N} \mathrm{L}^{-1}\right)\end{array}$ \\
\hline Control & 0.39 & 0.69 & 1.99 & 0.45 & 0.0006 & 1.84 \\
\hline T1 & 0.63 & 0.68 & 2.78 & 0.88 & 0.65 & 2.67 \\
\hline T2 & 0.71 & 0.62 & 3.98 & 0.91 & 0.69 & 3.72 \\
\hline T3 & 0.81 & 0.96 & 5.88 & 0.93 & 0.98 & 3.28 \\
\hline T4 & 0.95 & 1.13 & 3.07 & 0.98 & 1.22 & 2.46 \\
\hline
\end{tabular}



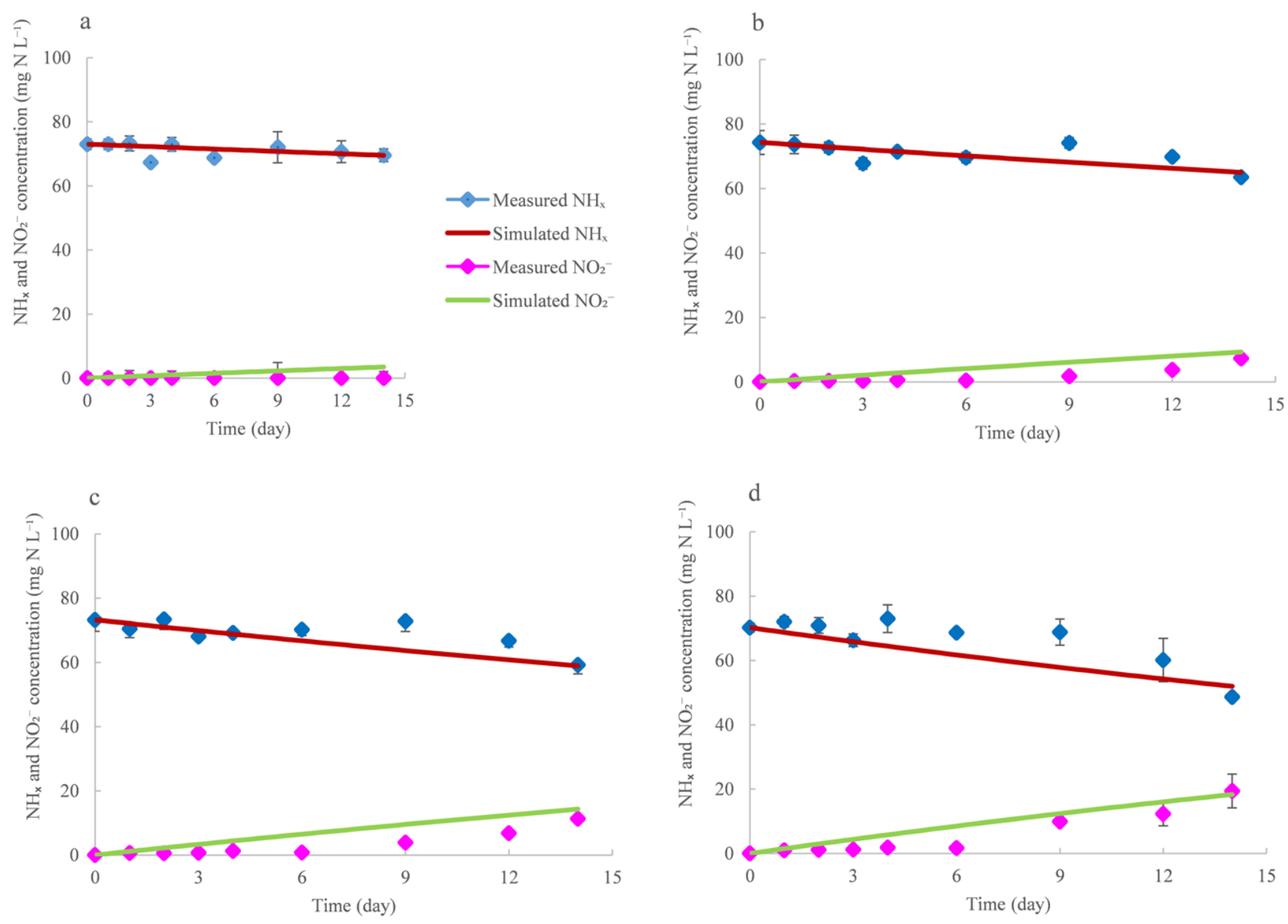

Fig. 7. Changes in average measured and predicted values of $\mathrm{NH}_{x}$ and $\mathrm{NO}_{2}$ in the validation exercise: (a) control (without mat); (b) $\mathrm{T}_{1}$ (4 $\mathrm{cm}^{2}$ mat material), (c) $\mathrm{T}_{2}\left(8 \mathrm{~cm}^{2}\right.$ mat material), (d) $\mathrm{T}_{3}\left(12 \mathrm{~cm}^{2}\right.$ mat material) and (e) $\mathrm{T}_{4}\left(16 \mathrm{~cm}^{2}\right.$ mat material). Error bars show standard deviations for measured concentrations.

all treatments, there was a progressive increase in electrical conductivity over the experiment (Fig. 4c). This was probably due to the increase of $\mathrm{NO}_{2}^{-}$concentration in all the treatments.

\section{Model performance (experiment 1)}

Observed and modeled (calibrated) concentrations of $\mathrm{NH}_{\mathrm{x}}$ and $\mathrm{NO}_{2}^{-}$for the $\mathrm{T}_{5}$ treatment are shown in Fig. 6. Optimized RMSE values were 4.06 and $0.98 \mathrm{mg} \mathrm{N} \mathrm{L}^{-1}$ for $\mathrm{NH}_{\mathrm{x}}$ and $\mathrm{NO}_{2}^{-}$, respec- tively. The good fit demonstrates that the model was able to reproduce the concentrations of $\mathrm{N}$ species well and that the rate of nitrite accumulation was consistent with the rate of ammonia loss (i.e., nitrification was the principal process).

Calibrated value of $k_{\text {nit }}$ for $\mathrm{T}_{5}$ alongside with the calculated values for independent treatments $k_{\text {inde }}\left(\mathrm{T}_{1}, \mathrm{~T}_{2}, \mathrm{~T}_{3}\right.$, and $\left.\mathrm{T}_{4}\right)$ are presented in Table 4.

Measured and simulated time series for $\mathrm{NH}_{\mathrm{x}}$ and $\mathrm{NO}_{2}^{-}$in the other treatments are shown in Fig. 7. $\mathrm{R}^{2}$, slope regression line, 


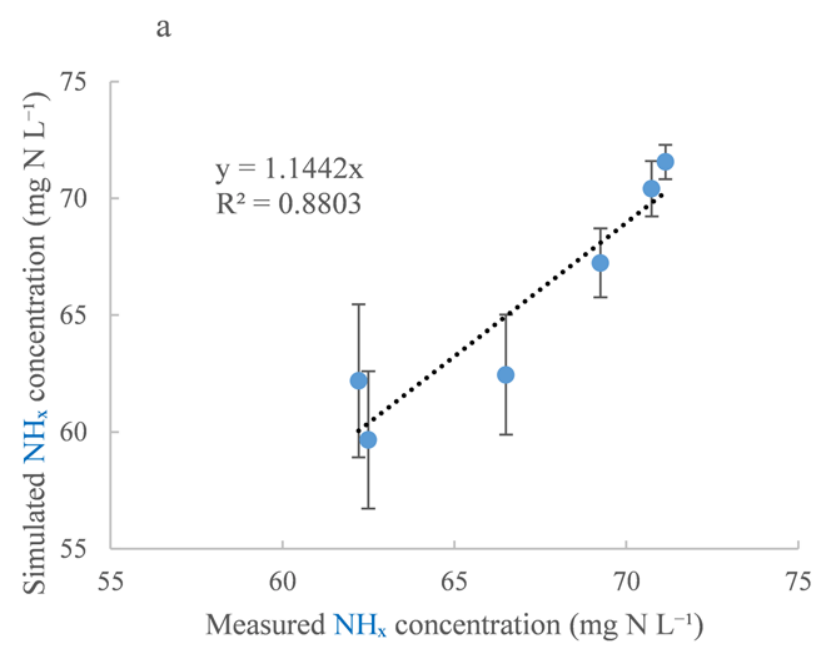

$\mathrm{b}$

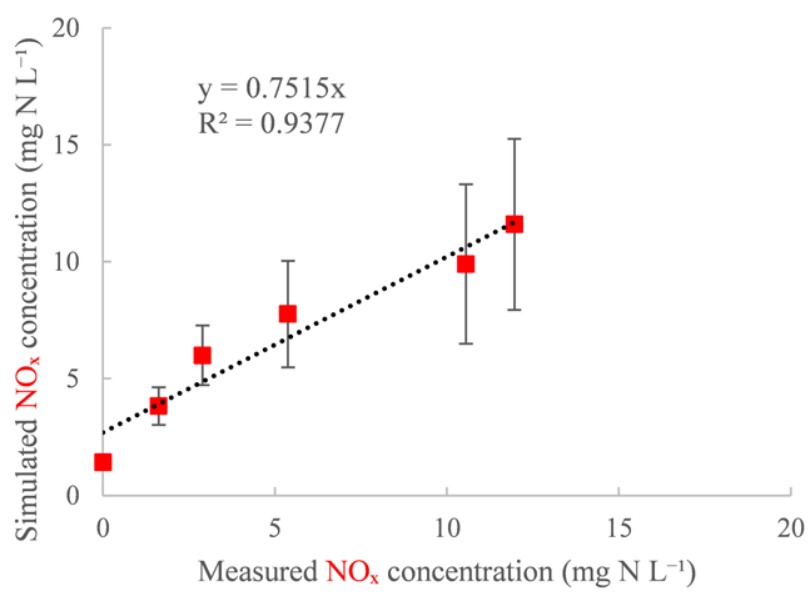

Fig. 8. Final average measured and simulated concentrations of (a) $\mathrm{NH}_{x}$ and (b) $\mathrm{NO}_{2}^{-}$in the validation treatments. Error bars show standard deviation for measured concentration.

Table 6. Net removal (mg N L-1), rate constant $\left(k\right.$, day $\left.{ }^{-1}\right)$, and halflives $\left(T_{1 / 2}\right.$, day) for the $\mathrm{NH}_{\mathrm{x}}$ concentrations in the treatments.

\begin{tabular}{|c|c|c|c|}
\hline & $\begin{array}{c}\text { Net removal } \\
\left(\mathrm{mg} \mathrm{N} \mathrm{L}^{-1}\right)\end{array}$ & $\begin{array}{c}\boldsymbol{k} \\
\left(\text { day }^{-1}\right)\end{array}$ & $\begin{array}{c}\boldsymbol{T}_{1 / 2} \\
\left(\text { day }^{-1}\right.\end{array}$ \\
\hline $\mathrm{T}_{1}$ & 15.74 & 0.53 & 1.29 \\
\hline $\mathrm{T}_{2}$ & 15.67 & 0.57 & 1.21 \\
\hline $\mathrm{T}_{3}$ & 29.03 & 0.17 & 4.12 \\
\hline $\mathrm{T}_{4}$ & 28.05 & 0.17 & 4.07 \\
\hline $\mathrm{T}_{5}$ & 31.85 & 0.05 & 13.33 \\
\hline $\mathrm{T}_{6}$ & 36.90 & 0.07 & 10.34 \\
\hline
\end{tabular}

and RMSE values between the mean observed and predicted concentrations are shown in Table 5. Overall, there is a good agreement between model prediction and measured data for most treatment. This suggests that the mat area provides an adequate scaling factor for the experimental system and supports the hypothesis that nitrifier biomass and activity are proportional to mat surface area.

Although the trends of $\mathrm{NH}_{\mathrm{x}}$ and $\mathrm{NO}_{\mathrm{x}}$ concentrations were generally captured well, the model performed poorly in some points in some treatments. For example, the initial rate of increase in $\mathrm{NO}_{2}{ }^{-}$concentrations was overpredicted for $\mathrm{T}_{1}, \mathrm{~T}_{2}$, and $\mathrm{T}_{3}$. This is due to the apparent lag phase in the observed data for these treatments, which was not taken into account in the model.

The results suggest that the submerged surface area provided by operational FTWs will support the growth of microbes and could significantly increase $\mathrm{N}$ removal compared with conventional free surface constructed wetlands (Stewart et al., 2008). The results support the findings reported by Zhang et al. (2016), of significant promotion of nitrification $(82 \%)$ in the presence of floating islands in an experimental system containing synthetic wastewater. The final measured concentrations are plotted against modeled values in Fig. 8. Overall, there is a good agreement in final concentrations for both $\mathrm{NH}_{\mathrm{x}}$ and $\mathrm{NO}_{2}^{-}\left(\mathrm{R}^{2}=0.88\right.$ and 93; slopes $=1.14$ and $0.75 \mathrm{mg} \mathrm{N} \mathrm{L}^{-1}$, respectively).

Overall, the good agreement between the modeled and measured data of $\mathrm{NH}_{x}$ and $\mathrm{NO}_{2}{ }^{-}$concentrations suggests that the model well described different treatment investigated under different mat surface areas. Keeping other factors controlled and no limits to the microbial activity (e.g., $\mathrm{O}_{2}$ limitation), these results support our hypothesis that the mat area can be used as a design parameter to optimize system performance in removing ammonia. Ammonia removal is directly proportional to the increase in mat area and therefore established microbial biofilm.

\section{Effect of ammonia concentrations and aeration (experiment 2)}

The similarity between the total oxidized $\mathrm{N}$ and nitrite concentrations observed in experiment 1 suggested that the second stage of nitrification was inhibited (i.e., that Nitrobacter type organisms were unable to grow and or operate efficiently). This could be due to high $\mathrm{NH}_{3}$ concentrations, which are known to affect Nitrobacter more. We also hypothesized that aeration could enhance nitrification rates through increased DO concentration available for nitrifier biosynthesis and activity. To test these ideas, the performance of the experimental system was examined under different total ammonia concentrations with and without aeration. Changes in $\mathrm{NH}_{x}, \mathrm{NO}_{2}^{-}$, and $\mathrm{NO}_{x}$ concentrations over time for the different treatments are shown in Fig. 9. $\mathrm{NH}_{\mathrm{x}}$ loss differed between treatments. There was an apparent lag phase in

Table 7. Average concentrations of $\mathrm{NH}_{3}$ in the treatments throughout the experiment.

\begin{tabular}{|c|c|c|c|c|c|c|}
\hline & \multicolumn{5}{|c|}{ Treatments } \\
\hline & $\mathbf{T}_{1}$ & $\mathbf{T}_{2}$ & $\mathbf{T}_{3}$ & $\mathbf{T}_{4}$ & $\mathbf{T}_{5}$ & $\mathbf{T}_{6}$ \\
\hline $\begin{array}{c}\mathrm{NH}_{3} \\
\left(\mathrm{mg} \mathrm{N} \mathrm{L}^{-1}\right)\end{array}$ & $0.1 \pm 0.09$ & $0.09 \pm 0.09$ & $0.27 \pm 0.15$ & $0.26 \pm 0.15$ & $0.7 \pm 0.17$ & $0.66 \pm 0.20$ \\
\hline
\end{tabular}



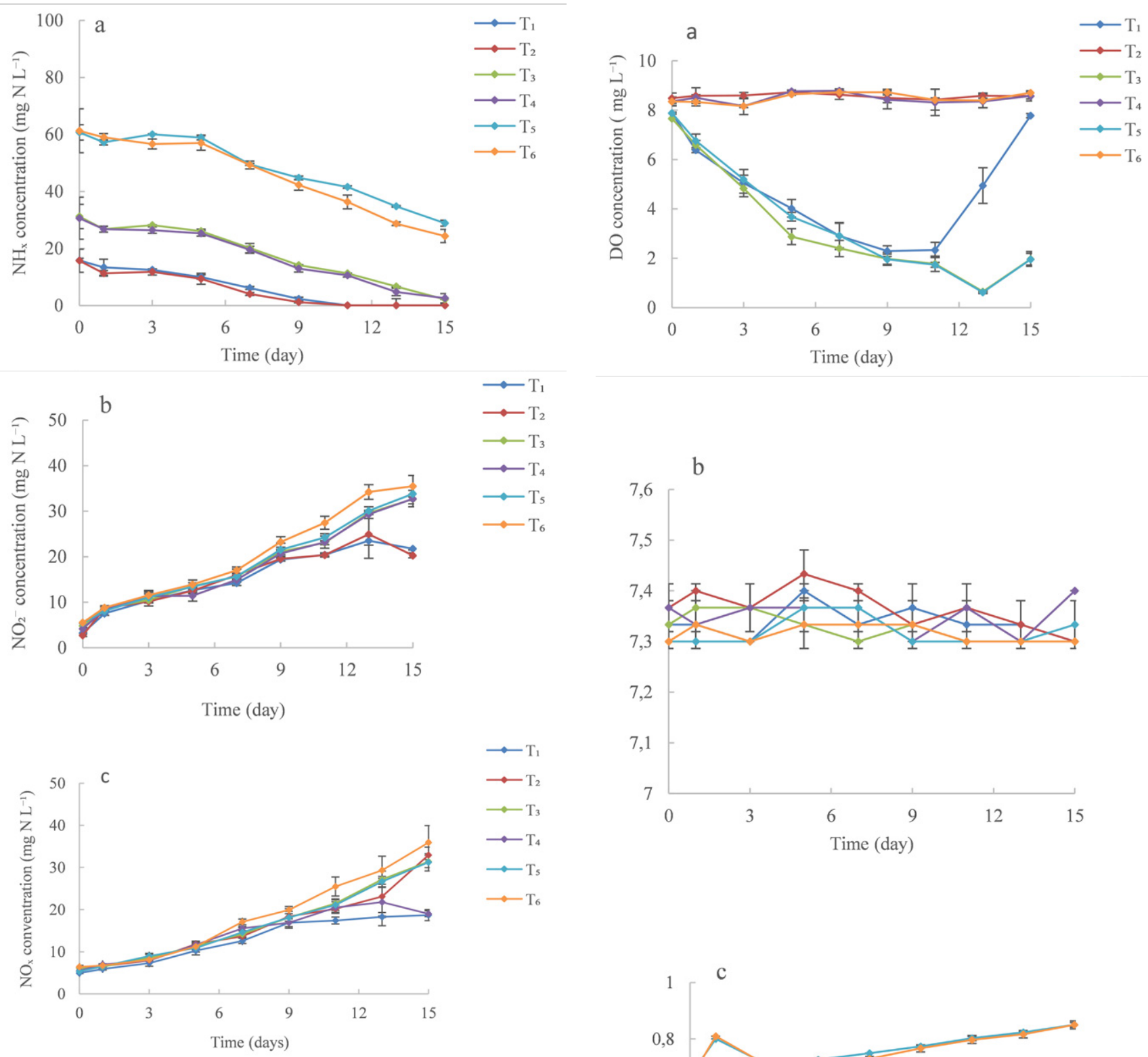

Fig. 9. Changes in the concentration of (a) $\mathrm{NH}_{x}$, (b) $\mathrm{NO}_{2}^{-}$, (c) $\mathrm{NO}$ in the treatments during experimental time (mean \pm standard deviation). $\mathrm{T}_{1}\left(15 \mathrm{mg} \mathrm{N} \mathrm{L}^{-1}\right) ; \mathrm{T}_{2}\left(15 \mathrm{mg} \mathrm{N} \mathrm{L}^{-1}\right.$, aeration); $\mathrm{T}_{3}\left(30 \mathrm{mg} \mathrm{N} \mathrm{L}^{-1}\right) ; \mathrm{T}_{4}$ (30 $\mathrm{mg} \mathrm{N} \mathrm{L}^{-1}$, aeration); $\mathrm{T}_{5}\left(60 \mathrm{mg} \mathrm{N} \mathrm{L}^{-1}\right) ; \mathrm{T}_{6}\left(60 \mathrm{mg} \mathrm{N} \mathrm{L}^{-1}\right.$, aeration).

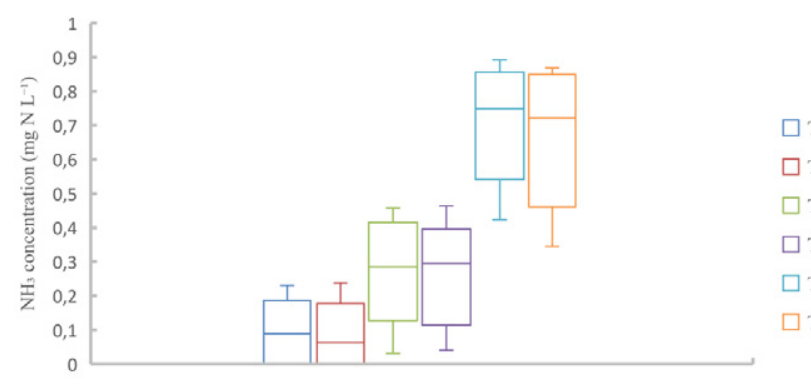

Treatments

Fig. 10. Concentration of $\mathrm{NH}_{3}$ in treatments under different ammonia $\mathrm{N}$ concentrations with and without aeration.
Fig. 11. Changes of (a) DO; (b) pH and (c) EC in the treatments during experimental time (mean \pm standard deviation). $\mathrm{T}_{1}(15 \mathrm{mg}$ $\left.\mathrm{N} \mathrm{L}^{-1}\right) ; \mathrm{T}_{2}\left(15 \mathrm{mg} \mathrm{N} \mathrm{L}^{-1}\right.$, aeration); $\mathrm{T}_{3}\left(30 \mathrm{mg} \mathrm{N} \mathrm{L}^{-1}\right) ; \mathrm{T}_{4}\left(30 \mathrm{mg} \mathrm{N} \mathrm{L}^{-1}\right.$, aeration); $\mathrm{T}_{5}\left(60 \mathrm{mg} \mathrm{N} \mathrm{L}^{-1}\right) ; \mathrm{T}_{6}\left(60 \mathrm{mg} \mathrm{N} \mathrm{L}^{-1}\right.$, aeration). 

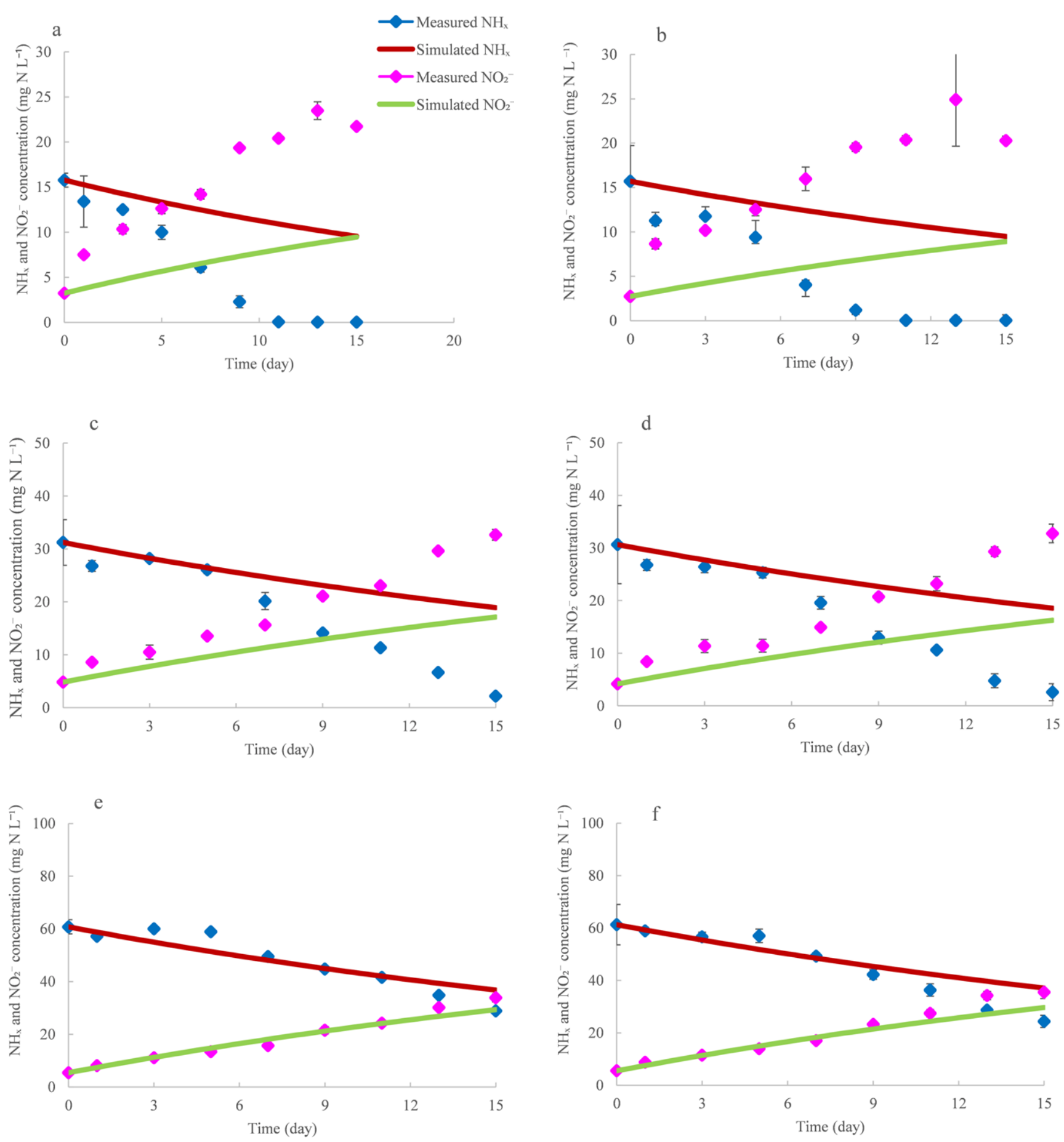

Fig. 12. Changes in average measured and predicted values of $\mathrm{NH}_{\mathrm{x}}$ and $\mathrm{NO}_{2}^{-}$in the validation exercise: (a) $\mathrm{T}_{1}\left(15 \mathrm{mg} \mathrm{N} \mathrm{L}^{-1}\right)$; (b) $\mathrm{T}_{2}\left(15 \mathrm{mg} \mathrm{N}^{-}\right.$ $\mathrm{L}^{-1}$, aeration); (c) $\mathrm{T}_{3}\left(30 \mathrm{mg} \mathrm{N} \mathrm{L}^{-1}\right)$; (d) $\mathrm{T}_{4}\left(30 \mathrm{mg} \mathrm{N} \mathrm{L}^{-1}\right.$, aeration); (e) $\mathrm{T}_{5}\left(60 \mathrm{mg} \mathrm{N} \mathrm{L}^{-1}\right)$ and $\mathrm{T}_{6}\left(60 \mathrm{mg} \mathrm{N} \mathrm{L}^{-1}\right.$, aeration). Error bars show standard deviations for measured concentrations.

$\mathrm{NH}_{\mathrm{x}}$ loss in all treatments up to day 5 , but the lag appeared to be more pronounced in the treatments with the highest initial $\mathrm{NH}_{x}$ concentrations.

First-order rate constants fitted to the $\mathrm{NH}_{\mathrm{x}}$ data show that the overall loss was higher in the treatments with the lowest initial $\mathrm{NH}_{\mathrm{x}}$ concentrations and lowest in those treatments with high initial $\mathrm{NH}_{\mathrm{x}}$ concentrations (Table 6). Consistently, higher net removal was observed in the treatments with low $\mathrm{NH}_{\mathrm{x}}$ concentrations than with high. However, $T_{1 / 2}$ values were low in treatments treated with low $\mathrm{NH}_{\mathrm{x}}$ concentration $\left(\mathrm{T}_{1}\right.$ and $\left.\mathrm{T}_{2}\right)$ compared to those treated with high concentrations $\left(\mathrm{T}_{3}, \mathrm{~T}_{4}, \mathrm{~T}_{5}\right.$, and $\left.\mathrm{T}_{6}\right)$. No significant differences were observed in the $\mathrm{NH}_{\mathrm{x}}$ between treat- 
Table 8. Statistical analysis for model performance.

\begin{tabular}{|c|c|c|c|c|c|c|}
\hline & \multicolumn{3}{|c|}{$\mathrm{NH}_{\mathrm{x}}$} & \multicolumn{3}{c|}{ NO $_{2}^{-}$} \\
\hline & $\mathrm{R}^{2}$ & $\begin{array}{c}\text { Slope } \\
\left(\mathrm{mg} \mathrm{N} \mathrm{L}^{-1}\right)\end{array}$ & $\begin{array}{c}\text { RMSE } \\
\left(\mathrm{mg} \mathrm{N} \mathrm{L}^{-1}\right)\end{array}$ & $\mathrm{R}^{2}$ & $\begin{array}{c}\text { Slope } \\
\left(\mathrm{mg} \mathrm{N} \mathrm{L}^{-1}\right)\end{array}$ & $\begin{array}{c}\mathrm{RMSE} \\
\left(\mathrm{mg} \mathrm{N} \mathrm{L}^{-1}\right)\end{array}$ \\
\hline $\mathrm{T}_{1}$ & 0.95 & 2.81 & 7.14 & 0.95 & 3.08 & 9.51 \\
\hline $\mathrm{T}_{2}$ & 0.92 & 2.67 & 7.63 & 0.90 & 3.04 & 10.27 \\
\hline $\mathrm{T}_{3}$ & 0.94 & 2.29 & 8.70 & 0.96 & 2.14 & 8.29 \\
\hline $\mathrm{T}_{4}$ & 0.95 & 2.34 & 8.95 & 0.95 & 2.21 & 8.81 \\
\hline $\mathrm{T}_{5}$ & 0.89 & 1.30 & 4.34 & 0.96 & 1.13 & 2.07 \\
\hline $\mathrm{T}_{6}$ & 0.93 & 1.54 & 6.30 & 0.96 & 1.25 & 3.34 \\
\hline
\end{tabular}

ments with and without aeration $(p<0.05)$ despite the marked differences in DO concentrations (see Fig. 10).

Lower rate constants in treatments with high initial ammonia- $\mathrm{N}$ concentration suggest that the nitrifiers may have been inhibited by high $\mathrm{NH}_{3}$ concentrations in the treatments. It has been well documented that $\mathrm{NH}_{3}$ have toxic impacts on nitrification (Daalkhaijav, Nemati, 2014; Ruiz et al., 2003; Vadivelu et al., 2007). Partially for $\mathrm{NO}_{2}^{-}$, ammonia oxidizing bacteria (AOB) are known to be more tolerant to $\mathrm{NH}_{3}$ than nitrite oxidizing bacteria (NOB) in activated sludge systems (Qiao et al., 2010).

Nitrite concentrations gradually increase in all treatments over the study period (Fig. 9b). Rates of $\mathrm{NO}_{2}{ }^{-}$production were consistent with rates of $\mathrm{NH}_{\mathrm{x}}$ loss. Significant differences in $\mathrm{NO}_{2}{ }^{-}$ production between treatments were observed (ANOVA, $F_{5,54}=$ 6.576; $P<0.05)$. The net production of $\mathrm{NO}_{2}{ }^{-}$were by $18.48,17.53$, 27.82, 28.59, 28.41, and $29.95 \mathrm{mg} \mathrm{N} \mathrm{L}^{-1}$ in $\mathrm{T}_{1}, \mathrm{~T}_{2}, \mathrm{~T}_{3}, \mathrm{~T}_{4}, \mathrm{~T}_{5}$, and $\mathrm{T}_{6}$ treatments, respectively. $\mathrm{NO}_{2}{ }^{-}$concentrations stopped increasing in $\mathrm{T}_{1}$ and $\mathrm{T}_{2}$ (lowest $\mathrm{NH}_{\mathrm{x}}$ concentration) at 15 days, which is coincident with the exhaustion of $\mathrm{NH}_{\mathrm{x}}$ supply in their treatments.

Like the findings of experiment 1 , obtained data showed that the total oxidized $\mathrm{N}$ was characterized by $\mathrm{NO}_{2}{ }^{-}$concentrations, but no analytical evidence of $\mathrm{NO}_{3}^{-}$generation (Fig.9c).

Free ammonia generation alongside with their average concentrations in the treatments over the course of the experiment are presented in Fig. 10 and Table 7. Higher concentration of $\mathrm{NH}_{3}$ was observed in the treatments with high concentration of total ammonia $\left(\mathrm{T}_{5}\right.$ and $\mathrm{T}_{6}$ ) compared to those exposed to low $\mathrm{NH}_{\mathrm{x}}$ levels $\left(\mathrm{T}_{1}, \mathrm{~T}_{2}, \mathrm{~T}_{3}\right.$, and $\left.\mathrm{T}_{4}\right)$.

The differences of the metabolic responses to the toxic effects of $\mathrm{NH}_{3}$ on the nitrifying population have been proposed as the primary cause resulting in NOB elimination (Sun et al., 2015). For instance, Vadivelu et al. (2007) found that the growth of Nitrobacter was decreased by $12 \%$ when $\mathrm{NH}_{\mathrm{x}}$ concentration increased from 0 to $9 \mathrm{mg} \mathrm{N} \mathrm{L}^{-1}$, indicating inhibitory effects on the respiratory capacity of the genus. Also, Philips et al., (2002) reported that the $\mathrm{NH}_{3}$ inhibition threshold for Nitrobacter in the range of $0.02-0.82 \mathrm{mg} \mathrm{NH}_{3}-\mathrm{N} \mathrm{L}^{-1}$. This could explain the higher accumulated rates of $\mathrm{NO}_{2}^{-}$in the treatments as the $\mathrm{NH}_{3}$ concentration is increased in the present study.

Treatments that were aerated had DO concentration close to the equilibrium level for the system temperature $\left(8.5 \mathrm{mg} \mathrm{L}^{-1}\right)$. However, in treatments that were not aerated, DO concentrations declined progressively due to oxygen consumption in nitrification (Fig. 11a). However, even the lowest oxygen level observed in the nonaerated treatments (an average of $3.96 \pm 0.76 \mathrm{mg}$ DO $\mathrm{L}^{-1}$ ), nitrification was observed to be proceeded (i.e., DO not limit). A notable recovery of DO concentration in $\mathrm{T}_{1}$ treatment
Table 9. Statistical analysis for model performance.

\begin{tabular}{|c|c|c|}
\hline Treatment & Optimised $\boldsymbol{k}_{\text {nit }}\left(\mathbf{d a y}^{-1}\right)$ & Optimised $\boldsymbol{k}_{\text {nit }} / \mathbf{T}_{\mathbf{5}} \boldsymbol{k}_{\text {nit }}$ \\
\hline $\mathrm{T}_{1}$ & 0.16 & \\
\hline $\mathrm{T}_{2}$ & 0.17 & 4.8 \\
\hline $\mathrm{T}_{3}$ & 0.09 & 5.3 \\
\hline $\mathrm{T}_{4}$ & 0.08 & 2.8 \\
\hline $\mathrm{T}_{5}$ & 0.04 & 2.5 \\
\hline $\mathrm{T}_{6}$ & 0.05 & 1.2 \\
\hline
\end{tabular}

at the end of the experiment was probably due to the oxygen concentration in this treatment was able to return to saturation levels once this sink was switched off. $\mathrm{NH}_{\mathrm{x}}$ depletion in this treatment and a consequent decline in nitrification (the main sink for dissolved $\mathrm{O}_{2}$ ).

Although blowing air in the system could encourage volatilization through the stripping process, however, the first-order $\mathrm{NH}_{3}$ volatilization rate constant at $\mathrm{pH}$ range between 7.3 and 7.4 (Fig.11b) was calculated to be 0.001 day $^{-1}$. Generally, all treatments showed a gradual increase in EC over the course of the experiment (Fig. 11c). Such increase was consistent with the extent of $\mathrm{NO}_{2}^{-}$concentrations produced in the treatments during the experiment.

\section{Model performance (experiment 2)}

Modeled and measured concentrations of $\mathrm{NH}_{\mathrm{x}}$ and $\mathrm{NO}_{2}{ }^{-}$for $\mathrm{T}_{5}$ model from experiment 1 against treatments from experiment 2 are shown in Fig.12. RMSE values between the measured and predicted concentrations are shown in Table 8.

Although measured and observed time series for $\mathrm{NH}_{\mathrm{x}}$ and $\mathrm{NO}_{2}{ }^{-}$concentrations in the $\mathrm{T}_{6}$ and $\mathrm{T}_{5}$ were generally captured well, the model performed poorly in other treatments. This is due to the apparent inhibition effect of free $\mathrm{NH}_{3}$ on the nitrifiers at a high level of ammonia $\mathrm{N}$ concentrations.

Table 9 compares best fits from all treatments. The ratio of optimized $k_{\text {nit }}$ to calibrated $\mathrm{T}_{5}$ model $\left(\mathrm{T}_{5} k_{\text {nit }}\right)$ was used as a quantitative index of the extent of nitrifiers inhibition by $\mathrm{NH}_{3}$.

These results suggest different extents of inhibition effects of free $\mathrm{NH}_{3}$ on nitrification as a consequence of nitrifiers activity depression. High ratio of the optimized $k_{\text {nit }}$ to calibrated $k_{\text {nit }}$ were observed in the treatments treated with low $\mathrm{NH}_{\mathrm{x}}$ concentrations, while low ratio was associated with treatments with high concen- 
tration of $\mathrm{NH}_{\mathrm{x}}$. High index indicates low inhibition effect of $\mathrm{NH}_{3}$ on nitrification at low concentration of ammonia, but low index indicates higher inhibition with higher concentration.

\section{Discussion}

The results of this study provide clear evidence that an increased amount of biofilm (introduced as an increased area of the mat) can increase ammonia removal rates. The relationship between ammonia removal and increase in surface area for microbial growth suggested that $T_{5}$ was best design for treatment performance. Microbial removal pathways, particularly nitrification, are mediated by fixed biofilms that occur on solid surfaces such as bed sediment, plant roots, and floating mats (Boltz et al., 2017; Stepanova et al., 2021). The results are broadly comparable with the findings obtained by Stewart et al. (2008). These authors looked at ammonia removal in water containing a high concentration of $200 \mathrm{mg} \mathrm{N} \mathrm{L}^{-1}$ under full cover of a floating matrix. They found a reduction in ammonium concentration of $\sim 70 \%$ compared to controls over 16 days. In the experiments reported in this study, increased $\mathrm{NO}_{2}^{-}$concentrations in the treatments suggests that (i) nitrification was the most plausible cause of ammonia removals, and (ii) microbial capacity for converting $\mathrm{NO}_{2}{ }^{-}$to $\mathrm{NO}_{3}^{-}$was inhibited. This was probably due to the toxic effect of unionized ammonia $\left(\mathrm{NH}_{3}\right)$ on Nitrobacter. Philips et al. (2002) showed that NOB organisms could be inhibited at an $\mathrm{NH}_{3}$ concentration of $0.6 \mathrm{mg} \mathrm{N} \mathrm{L}^{-1}$ in the batch reactors (i.e., total ammoniacal concentration of $13 \mathrm{mg} \mathrm{N} \mathrm{L}^{-1}$ at $20^{\circ} \mathrm{C}$ and $\mathrm{pH} 7.8$ ).

The explanation of ammonia loss by accelerated nitrification rates by increasing attachment surface area for the microbial biofilm (via increased submerged mat material) was also supported by the reduction of DO. Oxygen concentration was negatively correlated with the apparent nitrification rate (i.e., higher DO consumption by the increased microbial activity). The loss of oxygen was proportional to the loss rate of ammonia and the rate of $\mathrm{NO}_{2}^{-}+\mathrm{NO}_{3}^{-}$production.

There was a reasonable agreement between observed and predicted $\mathrm{N}$ dynamics in different treatments. Calibrated data from the $\mathrm{T}_{5}$ treatment was validated on the other treatments with rate constants adjusted in accordance with specific hypotheses, for example, nitrification rate constant will be directly proportional to mat surface area and therefore with the amount of established biofilm.

Nitrification rates were higher in treatments subjected to lower ammonia concentrations, which is in agreement with other published studies, for example, Andersson (2005) who reported lower nitrogen removal in free water surface wetland receiving a concentration of $37 \mathrm{mg} \mathrm{N} \mathrm{L}^{-1}$ of ammonia-N such as municipal or domestic wastewater. Slower nitrification rates observed at high initial concentrations might be due to the toxic effect of $\mathrm{NH}_{3}$ on nitrifiers' growth. There is a general agreement that free ammonia has an inhibitory effect on both AOB and NOB (Ciudad et al., 2005; Sun et al., 2015). NOB tends to be more sensitive than AOB (Al Obaidy, Lami, 2014; Park et al., 2015). Initial inhibiting concentrations of $\mathrm{NH}_{3}$ for Nitrosomonas and Nitrobacter activity are typically between $10-150$ and $0.1-1.0 \mathrm{mg} \mathrm{L}^{-1}$, respectively (Anthonisen et al., 1976). Here, $\mathrm{NH}_{\mathrm{x}}$ oxidation was slower in the treatment with an initial concentration of $60 \mathrm{mg} \mathrm{N}$ $\mathrm{L}^{-1}$, compared with an initial concentration of $15 \mathrm{mg} \mathrm{N} \mathrm{L}^{-1}$. Ni- trite accumulation was also high when $\mathrm{NH}_{\mathrm{x}}$ concentrations were high, which Nitrobacter growth inhibited. Peng and Zhu (2006) found that $\mathrm{NH}_{3}$ concentrations higher than $3.5 \mathrm{mg} \mathrm{NH}-\mathrm{N} \mathrm{L}^{-1}$ were sufficient to inhibit $\mathrm{NO}_{2}^{-}$oxidation. The results did not suggest an important role for aeration in ammonia removal (i.e., removal rates were not significantly different in aerated and nonaerated treatments). This was probably due to the fact that DO concentrations were generally $>1 \mathrm{mg} \mathrm{L}^{-1}$. Nitrification is known to be inhibited only at DO concentrations $<1 \mathrm{mg} \mathrm{L}^{-1}$ (Van Hulle et al., 2010). Nitrification was clearly a sink for DO. DO concentrations decreased in unaerated treatments in a classical "oxygen sag" but recovered in treatments where ammonia was exhausted.

\section{Conclusion}

The findings presented in this chapter suggest that the changes in the surface area of floating mat matrix can affect ammonia removal via nitrification. There was an approximately linear relationship between the removal rate constant and mat surface area. The higher ammonia removal efficiency was caused by a larger surface area, which could support the growth of more microbes. There was also a clear inhibitory effect on second-stage nitrification in experiment 1 manifested as low production of nitrate. This is probably due to very high ammonia concentrations. This was further investigated in experiment 2 in which ammonia concentration was varied. Here, there appeared to be an effect of increased $\mathrm{NH}_{\mathrm{x}}$ concentration on nitrification (with a higher rate of nitrification in treatments with lower initial $\mathrm{NH}_{\mathrm{x}}$ concentrations), which confirms the free ammonia toxicity hypothesis. However, $\mathrm{NO}_{3}{ }^{-}$production was still not observed. There was no major effect of oxygen saturation on $\mathrm{NH}_{\mathrm{x}}$ removal using aerated and nonaerated conditions.

Understanding of mineral $\mathrm{N}$ dynamics in the experiments described here was facilitated using a simple dynamic model. In experiment 1 , the model was calibrated using experimental data from one treatment $\left(\mathrm{T}_{5}\right)$ and validated on the other treatments after simple linear adjustments reflecting a priori hypotheses about the contribution of mat surface area. Considering the relatively simple nature of process representation, the model did a fairly good job in predicting $\mathrm{N}$ concentration dynamics and removal efficiencies. The findings also support the hypothesis underpinning the conversion of rate constants obtained via calibration in treatment $\mathrm{T}_{5}$.

Overall, the findings show that increasing surface area of the floating mat improves the efficiency of ammonia removal and that high free ammonia concentrations can depress nitrification. The work demonstrates the use of a simple dynamic model as a framework to improve a mechanistic understanding of $\mathrm{NH}_{x}$ removal under different experimental conditions. Upscaling the knowledge of ammonia behavior obtained from well-controlled lab experiment to less-controlled field studies has the potential to improve understanding of the ammonia behavior at different experimental conditions.

\section{Acknowledgements}

This project was funded by the Higher Committee for Education Development in Iraq as a part of full-time PhD scholarship. The authors would like to give our thanks and gratitude to the constructive feedback and comments from reviewers and editor. 


\section{References}

Abadi, L.S.K., Shamsai, A. \& Goharnejad H. (2015). An analysis of the sustainability of basin water resources using Vensim model. KSCE Journal of Civil Engineering, 19(6), 1941-1949. DOI: 10.1007/s12205-0140570-7.

Allami, M.H.M., Whelan, M.J., Boom, A. \& Harper D.M. (2021). Am monia removal in free-surface constructed wetlands employing synthetic floating islands. Baghdad Science Journal, 18(2), 253-267. DOI 10.21123/bsj.2021.18.2.0253.

Al Obaidy, A.M.J. \& Lami M.H.M. (2014). The toxic effects of crude oil in some freshwater cyanobacteria. Journal of Environmental Protection, 5(5), 359-367. DOI: 10.4236/jep.2014.55039.

Al Obaidy, A.M.J., Lami, M.H.M. \& Al-Janabi Z.Z. (2017). Crude oil removal via isolated cyanobacteria in presence of linear alkyl benzene sulfonates. Desalination and Water Treatment, 88, 230-234. DOI: 10.5004/ dwt.2017.21400.

Andersson, J.L., Bastviken, S.K. \& Tonderski K.S. (2005). Free water surface wetlands for wastewater treatment in Sweden - nitrogen and phosphorus removal. Water Sci. Technol., 51(9), 39-46. DOI: 10.2166/ wst.2005.0283.

Anthonisen, A., Loehr, R., Prakasam, T. \& Srinath E. (1976). Inhibition of nitrification by ammonia and nitrous acid. Journal (Water Pollution Control Federation), 48(5), 835-852. https://www.jstor.org/stable/25038971.

Boltz, J.P., Smets, B.F., Rittmann, B.E., Van Loosdrecht, M.C.M., Morgenroth, E. \& Daigger G.T. (2017). From biofilm ecology to reactors: A focused review. Water Sci. Technol., 75(8), 1753-1760. DOI: 10.2166/ wst.2017.061

Borne, K.E., Fassman, E.A. \& Tanner C.C. (2013). Floating treatment wetland retrofit to improve stormwater pond performance for suspended solids, copper and zinc. Ecological Engineering, 54, 173-182. DOI10.1016/j.ecoleng.2013.01.031.

Cervantes, F.J. (2009). Environmental technologies to treat nitrogen pollution: Principles and engineering. London: IWA Publishing.

Chapman, B.D., Schleicher, M., Beuger, A., Gostomski, P. \& Thiele J.H. (2006). Improved methods for the cultivation of the chemolithoautotrophic bacterium Nitrosomonas europaea. J. Microbiol. Methods, 65(1), 96-106. DOI: 10.1016/j.mimet.2005.06.013.

Cheeseman, R., Wilson, A.L. \& Gardner M.J. (1989). A manual of analytical quality control for the water industry. Marlow, Buckinghamshire: Water Research Centre.

Chen, S., Ling, J. \& Blancheton J.P. (2006). Nitrification kinetics of biofilm as affected by water quality factors. Aquac. Eng., 34(3), 179-197. DOI 10.1016/j.aquaeng.2005.09.004.

Ciudad, G., Rubilar, O., Muñoz, P., Ruiz, G., Chamy, R., Vergara, C. \& Jeison D. (2005). Partial nitrification of high ammonia concentration wastewater as a part of a shortcut biological nitrogen removal process. Pro cess Biochem., 40(5), 1715-1719. DOI: 10.1016/j.procbio.2004.06.058.

Costerton, J.W., Lewandowski, Z., DeBeer, D., Caldwell, D., Korber, D. \& James G. (1994). Biofilms, the customized microniche. J. Bacteriol., 176(8), 2137-2142.

Daalkhaijav, U. \& Nemati M. (2014). Ammonia loading rate: An effective variable to control partial nitrification and generate the anaerobic ammonium oxidation influent. Environ. Technol., 35(5), 523-531. DOI: 10.1080/09593330.2013.796006.

EPA (1993). Methods for the determination of inorganic substances in environmental samples. Cincinnati: US Environmental Protection Agency.

Faulwetter, J.L., Burr, M.D., Cunningham, A.B., Stewart, F.M., Camper A.K. \& Stein O.R. (2011). Floating treatment wetlands for domestic wastewater treatment. Water Sci. Technol., 64(10), 2089-2095. DOI $10.2166 /$ wst. 2011.576

Field, A., Miles, J. \& Field Z. (2012). Discovering Statistics Using R. SAGE Publications.

Finnegan, C.J., van Egmond, R.A., Price, O.R. \& Whelan M.J. (2009). Continuous-flow laboratory simulation of stream water quality changes downstream of an untreated wastewater discharge. Water Res., 43(7), 1993-2001. DOI: 10.1016/j.watres.2009.01.031.

Hargreaves, J.A. (1998). Nitrogen biogeochemistry of aquaculture ponds. Aquaculture, 166(3-4), 181-212. DOI: 10.1016/s0044-8486(98)00298-1.
Headley, T.R. \& Tanner C.C. (2006). Application of floating wetlands for Enhanced Stormwater Treatment: A review. Hamilton: National Institute of Water and Atmospheric Research Ltd.

Ijaz, A., Shabir, G., Khan, Q.M. \& Afzal M. (2015). Enhanced remediation of sewage effluent by endophyte-assisted floating treatment wetlands. Ecological Engineering, 84, 58-66. DOI: 10.1016/j.ecoleng.2015.07.025.

Kadlec, R.H. \& Wallace S.D. (2009). Treatment wetlands. New York: CRC Press.

Karri, R.R., Sahu, J.N. \& Chimmiri V. (2018). Critical review of abatement of ammonia from wastewater. Journal of Molecular Liquids, 261, 21-31. DOI: 10.1016/j.molliq.2018.03.120.

Lin, Y.-F., Jing, S.-R., Lee, D.-Y. \& Wang T.-W. (2002). Nutrient removal from aquaculture wastewater using a constructed wetlands system. Aquaculture, 209(1), 169-184. DOI: DOI: 10.1016/S00448486(01)00801-8.

Mackay, D. (2001). Multimedia environmental models: The fugacity approach. CRC Press.

Maksimova, Y.G. (2014). Microbial biofilms in biotechnological processes. Applied Biochemistry and Microbiology, 50(8), 750-760. DOI: 10.1134/ s0003683814080043.

Park, S., Bae, W. \& Rittmann B.E. (2010). Operational boundaries for nitrite accumulation in nitrification based on minimum/maximum substrate concentrations that include effects of oxygen limitation, $\mathrm{pH}$, and free ammonia and free nitrous acid inhibition. Environ. Sci. Technol., 44(1), 335-342. DOI: 10.1021/es9024244.

Park, S., Chung, J., Rittmann, B.E. \& Bae W. (2015). Nitrite accumulation from simultaneous free-ammonia and free-nitrous-acid inhibition and oxygen limitation in a continuous-flow biofilm reactor. Biotechnol. Bioeng., 112(1), 43-52. DOI: 10.1002/bit.25326.

Peng, Y. \& Zhu G. (2006). Biological nitrogen removal with nitrification and denitrification via nitrite pathway. Appl. Microbiol. Biotechnol. 73(1), 15-26. DOI: 10.1007/s00253-006-0534-z.

Philips, S., Laanbroek, H.J. \& Verstraete W. (2002). Origin, causes and effects of increased nitrite concentrations in aquatic environments. Reviews in Environmental Science and Biotechnology, 1(2), 115-141. DOI 10.1023/a:1020892826575

Qiao, S., Matsumoto, N., Shinohara, T., Nishiyama, T., Fujii, T., Bhatti, Z \& Furukawa K. (2010). High-rate partial nitrification performance of high ammonium containing wastewater under low temperatures. Bioresour. Technol., 101(1), 111-117. DOI: 10.1016/j.biortech.2009.08.003.

Rohatgi, V.K. \& Saleh A.K.E. (2015). An introduction to probability and statistics. Hoboken: John Wiley \& Sons.

Rousseau, D.P., Vanrolleghem, P.A. \& De Pauw N. (2004). Model-based design of horizontal subsurface flow constructed treatment wetlands: a review. Water Res., 38(6), 1484-1493. DOI: 10.1016/j.watres.2003.12.013.

Ruiz, G., Jeison, D. \& Chamy R. (2003). Nitrification with high nitrite accumulation for the treatment of wastewater with high ammonia concentration. Water Res., 37(6), 1371-1377. DOI: 10.1016/s00431354(02)00475-x.

Safwat, S.M. (2018). Performance of moving bed biofilm reactor using effective microorganisms. Journal of Cleaner Production, 185, 723-731. DOI: $10.1016 /$ j.jclepro.2018.03.041.

SEAL Analytical (2011). Nitrate-N+Nitrite- $N$ in drinking and surface waters, domestic and industerial wastes. SEAL Analytical.

SEAL Analytical (2013). Nitrite- $N$ in drinking waters, treated waste waters, ground and surface waters. SEAL Analytical.

SEAL Analytical (2015). Ammonia-N in drinking and surface waters, domestic and industrial wastes. SEAL Analytical.

Shahot, K., Idris, A., Omar, R. \& Yusoff H.M. (2014). Review on biofilm processes for wastewater treatment. Life Sci., 11(11), 1-13.

Stepanova, L.P., Pisareva, A.V. \& Raskatov V.A. (2021). Assessment of the state of soils microbial community in condition of intensive influence of pollutants. Ekológia (Bratislava), 40(1), 8-15. DOI: 10.2478/eko2021-0002.

Stewart, F.M., Mulholland, T., Cunningham, A.B., Kania, B.G. \& Osterlund M.T. (2008). Floating islands as an alternative to constructed wetlands for treatment of excess nutrients from agricultural and municipal wastes - Results of laboratory-scale tests. Land Contamination and Reclamation, 16(1), 25-33. DOI: 10.2462/09670513.874. 
Sun, H., Peng, Y., Wang, S. \& Ma J. (2015). Achieving nitritation at low temperatures using free ammonia inhibition on Nitrobacter and real-time control in an SBR treating landfill leachate. J. Environ. Sci. (China), 30 157-163. DOI: 10.1016/j.jes.2014.09.029.

Tanner, C.C. \& Headley T.R. (2011). Components of floating emergent macrophyte treatment wetlands influencing removal of stormwater pollutants. Ecological Engineering, 37(3), 474-486. DOI: 10.1016/j. ecoleng.2010.12.012.

Vadivelu, V.M., Keller, J. \& Yuan Z. (2007). Effect of free ammonia on the respiration and growth processes of an enriched Nitrobacter culture. Water Res., 41(4), 826-834. DOI: 10.1016/j.watres.2006.11.030.

Van Hulle, S.W.H., Vandeweyer, H.J.P., Meesschaert, B.D., Vanrolleghem, P.A., Dejans, P. \& Dumoulin A. (2010). Engineering aspects and practical application of autotrophic nitrogen removal from nitrogen rich streams. Chem. Eng. J., 162(1), 1-20. DOI: 10.1016/j.cej.2010.05.037.
Vázquez-Burney, R., Bays, J., Messer, R. \& Harris J. (2015). Floating wetland islands as a method of nitrogen mass reduction: Results of a 1 year test. Water Sci. Technol., 72(5), 704-710. DOI: 10.2166/wst.2015.235.

Wang, J.-M., Gao, M.-Y., Xie, H.-J., Zhang, J. \& Hu Z. (2015). Application of biological island grids in wastewater treatment and its microbial mechanisms. Desalination and Water Treatment, 54(10), 2731-2738. DOI: 10.1080/19443994.2014.906322.

Whelan, M.J., Everitt, T. \& Villa R. (2010). A mass transfer model of ammonia volatilisation from anaerobic digestate. Waste Manag., 30(10), 1808-1812. DOI: 10.1016/j.wasman.2009.08.012.

Zhang, L., Zhao, J., Cui, N., Dai, Y., Kong, L., Wu, J. \& Cheng S. (2016) Enhancing the water purification efficiency of a floating treatment wetland using a biofilm carrier. Environ. Sci. Pollut. Res., 23(8), 7437-7443. DOI: $10.1007 / \mathrm{s} 11356-015-5873-9$. 